\title{
Regional needs save environmental projects
}

Munich. A German laboratory that has played a prominent role in addressing the environmental problems of East Germany is to be allowed to continue working in the environmental field, despite the recommendations of a top-level scientific committee that such work be wound up.

The proposal to close down work at the GKSS research centre near Hamburg, one of 16 national research laboratories in Germany, was made in a report on environmental research put together by a scientific subcommittee of the Wissenschaftsrat, the country's main science advisory body.

But, following criticism of the subcommittee's conclusions by the local region, the Wissenschaftsrat has now agreed that the centre should merely lose one of its outstations in east Germany, the Magdeburg-based Institute for Water Research. It will be allowed to continue its work on monitoring and assessing environmental damage.

The GKSS was established in 1956 to carry out research and development on nuclear-powered ships. But, like many other nuclear research facilities, it had to find new goals in the 1970s, and shifted nearly half of its activities into environmental research. It has also built up programmes in materials research and separation techniques.

According to the Wissenschaftsrat's science committee, which has just completed a two-year survey of environmental research in Germany, the change in direction had not been successful. "The research was just very weak," says Gotthilf Hempel, who headed the committee. "There were too many groups doing different things that were not very innovative and there was virtually no collaborative work."

As well as involving scientists, the main committee of the Wissenschaftsrat is made up of politicians from the federal and state (Länder) planning departments. Accommodating political pressure is a fact of life for the Wissenschaftsrat, according to its former head, zoologist Gerhard Neuweiler. As a result, the recommendations of scientific subcommittees are endorsed only if they receive broad political approval as well.

Not surprisingly, the more drastic of the environmental science committee's recommendations were apparently modified in the light of pressure on the main committee. In particular, the state of Schleswig-Holstein, where GKSS is located, opposed major cuts in its national research centre.

As a result, a compromise was reached. It was agreed that the centre should be allowed to continue with environmental research if it reduced the number of research projects and focused on its acknowledged strengths in environmental monitoring.
In fact the GKSS has already been moving in that direction. At the end of 1992, Günter von Sengbusch, an industrial medical engineer, became the centre's director and slowly gained the confidence of committee members. On the basis of an analysis of the centre's activities by external consultants, whose conclusions broadly coincided with those of the Wissenschaftsrat, he began to cut the number of research projects and

\section{IMAGE UNAVAILABLE FOR COPYRIGHT REASONS}

Ilution remains a problem in East Germany.

concentrate the centre's environmental activities on the management of coastal ecosystems in the Hamburg region.

The Wissenschaftsrat appears to have endorsed von Sengbusch's actions. But in a move that von Sengbusch describes as "regretful", its east German outpost, the Institute for Water Research, will transfer to the new national research centre for environmental research (UFZ) in Leipzig-Halle.

The institute had already been rescued once by the Wissenschaftsrat when it recommended two years ago as part of an evaluation of all east German research that the institute's two major research activities be saved. These concern the ecology of the badly polluted river Elbe, and the control of non-natural lakes on sites of abandoned coal mines.

The Wissenschaftsrat recommended that the institute either be established as an independent 'blue-list' institute - one for which the federal and regional governments share the costs equally - or merged with the newly established UFZ.

At the time, the GKSS, which is located at the Elbe estuary, successfully argued for a third alternative - that the two centres in west and east Germany that studied the river Elbe should be united.

Reinhold Leitterstorf, the head of the research ministry's environment department, now argues that the ministry "made a mistake" in ignoring the Wissenschaftsrat's advice and accepting the GKSS's plan. The Institute for Water Research will now be transferred from the beginning of January.

But the institute's director, Walter Geller, argues that the merger with the GKSS was appropriate for the time, since it saved the relatively poor Land of Sachsen-Anhalt a considerable amount of money (the federal government picks up 90 per cent of the bill for national research centres), the UFZ was still establishing itself, and the GKSS provided valuable technical support for water analysis, for which the institute was illequipped.

Geller says he is now equally happy with the institute's transfer to the UFZ, whose major task is to analyse and reverse the extensive environmental damage in eastern Germany. The move will allow the institute to build links with other UFZ programmes, such as those on the environmental impact of mines producing brown coal.

The GKSS was not the only target for criticism in the Wissenschaftsrat's report. Environmental research overall, which is generously funded, was criticized for being too fragmented, lacking the collaboration between research teams needed to raise the standard of their work to international level.

Such lack of collaboration, it said, was particularly apparent between universitybased research groups. Neuweiler argues that it is one reason why, despite some pockets of excellence, "Germany is not as internationally renowned in ecology as it should be".

The new report also suggests that a greater proportion of the funds now allocated for environmental research at the national research centres should be made available on a competitive basis to scientific groups in research institutes and universities.

Alison Abbott

\section{Italian to head bioinformatics institute}

Munich. The director of the European Bioinformatics Institute (EBI) in Cambridge, UK, the new outstation of the European Molecular Biology Laboratory (EMBL), is to be Paolo Zanella, a former head of computing services at the European Laboratory for Particle Physics (CERN) in Geneva.

The 60-year-old Zanella is currently research director of the Centro di Ricerca Sviluppo e Studi Superiori, a high per- formance computer centre which undertakes research and development for industry and research centres in Italy. Zanella helped to set up the centre, which is located in Sardinia, on leaving CERN in 1989 and still teaches at the University of Geneva.

The EBI will house and extend the European mammalian gene database, currently at EMBL's main laboratory in Heidelberg. 